\title{
HOW I GROW: Newborn through Month Two ${ }^{1}$
}

Millie Ferrer and Keith Gouin ${ }^{2}$

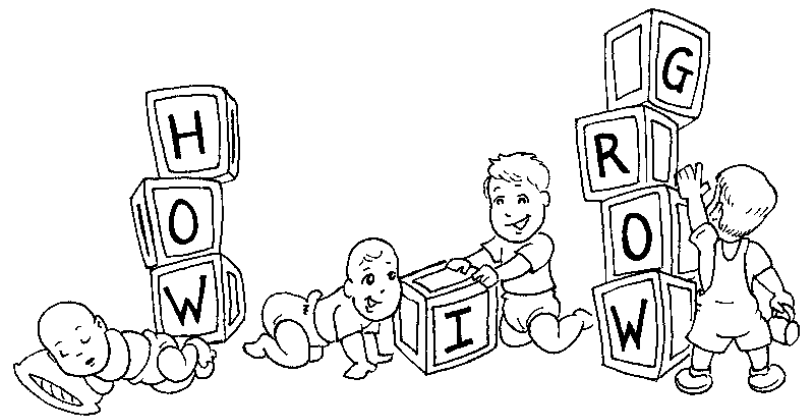

Congratulations! Your beautiful baby has finally arrived and now the fun really begins! There is nothing like the experience of watching a newborn grow and develop.

You will see incredible changes this first year. How you and other family members interact with your baby from the very beginning will have a significant impact on every aspect of his development. The special time and attention you give your infant now will reap great benefits for his future growth and success.

\section{Overview}

How I Grow is a series of six newsletters designed to inform and encourage you during your child's first year of life. The newsletters will discuss developmental changes in your baby, as well as highlight important milestones to keep in mind as you care for him. Do not forget that taking care of yourself is very important, too. Your child needs you! A healthy and happy parent will be able to help an infant develop physically, socially, emotionally, and intellectually.

\section{Physical Development}

Expect a newborn to sleep about 16 hours a day. Some infants will sleep for long periods, while others will wake up more often. When your baby does wake up, she will want to eat. At first almost all of her waking hours will be used for feeding. As time passes, she will spend more time exploring her environment and socializing with you.

When babies wake up, they often cry and need comforting. Your baby may be hungry, have a wet diaper, or need more rest. Some infants are easily comforted and others have a harder time, depending on their temperaments.

Temperament has to do with a child's inborn characteristics; her particular way of viewing the world. Temperament has to do with adaptability, mood, activity level, and the ability to soothe herself and be soothed by a caregiver. With time you will get a sense of how easy or hard it is to figure out what your infant needs.

Your baby will be comforted when you sing to her, rock her, or hold her close as you walk around the house. The important thing is to respond to her needs with tenderness and care. It is impossible to spoil a newborn.

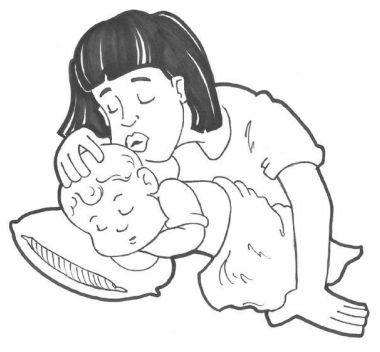

1. This document is FCS2217, one of a series of the Department of Family, Youth and Community Sciences, Florida Cooperative Extension Service, IFAS, University of Florida, Gainesville FL 32611. First published: August 2003. Reviewed by: Anne M. Fugate, former coordinator educational/training programs, Meredith Taylor, county extension director and extension agent IV, Live Oak and Gayle Whitworth, extension agent I, Cocoa, FL Thanks to Jason Greene for creating the artwork in this fact sheet. Please visit the EDIS Web site at http://edis.ifas.ufl.edu

2. Millie Ferrer, Ph.D., professor, and Keith Gouin, coordinator educational/training programs, Department of Family, Youth and Community Sciences, IFAS, University of Florida, Gainesville, FL 32611.

The Institute of Food and Agricultural Sciences is an equal opportunity/affirmative action employer authorized to provide research, educational information and other services only to individuals and institutions that function without regard to race, color, sex, age, handicap or national origin. For information on obtaining other extension publications, contact your county Cooperative Extension Service office. Florida Cooperative Extension Service/Institute of Food and Agricultural Sciences/University of Florida/Christine Taylor Waddill, Dean. 
Newborns can hear a wide variety of sounds.Infants as young as three days old turn their eyes and head in the general direction of a sound. Talk softly to your baby. Tell her how special she is. Talk to her about her family, about yourself, and about interesting things happening in the world around her. Avoid talking to her about negative situations and your worries. Play lullabies or peaceful music to comfort her when she is feeling stressed.

Your newborn's vision is the least mature of all of her senses. In the beginning, her vision is fuzzy, but she can still actively explore her environment by observing interesting sights and following moving objects. Place objects 7 to 8 inches away from her face and give her time to focus on the object and watch it. To foster the coordination of your baby's eyes and ears, gently shake a rattle or squeeze a squeaky ball where she can see it, then move it, and let her follow it with her eyes. At the beginning, she will not follow the ball from side to side, but as she continues to grow she will master this game. Your baby's vision will mature rapidly, and by the end of the second month she will really enjoy staring at objects and people, and tracking moving objects with her eyes.

In the beginning, your newborn's physical activities are mostly simple reflex actions. With time, some reflexes will disappear, while others will become permanent. For example, at first your baby will close her fists whenever the palm of her hand is touched. This is called the grasping reflex. At about two months, your baby's grasping reflex will be less apparent and her hand will be open more often. Soon she will be grasping objects on her own. For now, place objects in her hand so she can look at and enjoy them.

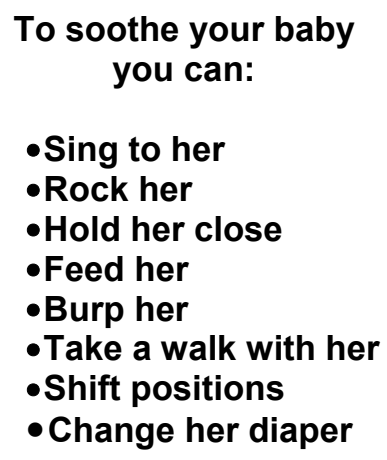

Your baby will soon begin performing other actions that will help her develop physically. She may hold her head up for longer periods; lift both feet off of the bed, or even rock back and forth when on her belly. In fact, make sure your baby is allowed to change position frequently to ensure equal development of all muscle groups. However, any time your infant is on her stomach, watch her closely. Do not allow your baby to sleep on her stomach because this has been linked to the occurrence of SIDS, or Sudden Infant Death Syndrome.

\section{Social Development}

Infants are social creatures! They thrive on your attention and love to see your smiling face.

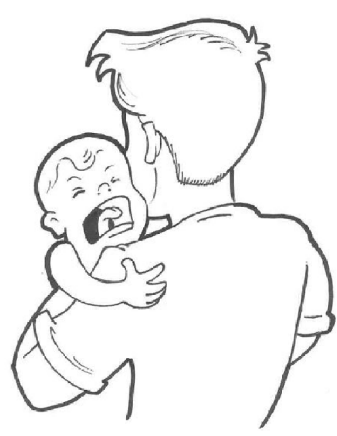

For a baby, out of sight is out of mind. So, if your baby can't see you, then you do not exist! So enjoy interacting face to face with your baby. By about the six-week mark, your baby will be smiling back at you!

How we interact with babies from day one has a significant impact on their development. It is extremely important to pay a lot of attention to your baby so that he will learn to trust you and feel very attached to you.

You have probably realized by now that babies communicate mostly by crying. Try to stay calm during these times so you can figure out what your baby needs. With time, most parents can recognize the difference between a cry of fear or pain and a cry of exhaustion or hunger. He will give you clues about what he is asking for. For example, your baby may turn away from you, squirm, or fuss when he's ready to take a break from play and have a little "down time." Stimulation is vital for the healthy development of your baby, but he also requires some personal space and a chance to rest on his own.

By the end of the second month, your baby may begin to make cooing sounds on his own or when you are talking with him. These are 
pleasant "ooo" type sounds that you will enjoy responding to. These sounds are the foundation for future communication between you and your baby. Enjoy talking with your baby even though you know he doesn't fully understand! This is fun and helps him develop socially and intellectually.

\section{Emotional Development}

By the second month it is usually obvious when your infant is afraid, happy, or uncomfortable. A happy baby may kick her feet or coo while thrashing her arms about. If she cries, she may be telling you that she is afraid and needs you to comfort her. Sometimes a

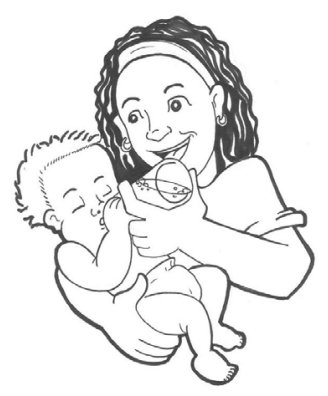
baby can get uncomfortable, and a change of clothes, a shift in position, or even a short walk outside may make her feel better. Your gentle and loving attention is vital for her development. In fact, studies have shown that babies cry less through the first year of life when they are quickly and lovingly responded to in times of need. These first months are a time when babies are developing trust and they need a safe environment with a caregiver who will respond to their needs.

A great time to express your love for your baby is during feeding time when you can tenderly caress her and hold her close. Always hold your infant when feeding her. Do not just prop a bottle up and let her feed on her own. Babies love for you to hug, cuddle, and smile at them during feeding.

\section{Intellectual Development}

Researchers have learned much about the intellectual development of children. Babies are born with about 100 billion brain cells, but the vital connections between cells are not formed at birth. These

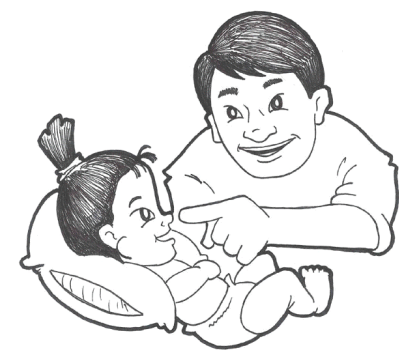

connections are built as your baby interacts with you and his surroundings. Babies who receive loving care and a stimulating environment will form a brain that is "wired" for continued growth and success. Without a stimulating environment, a baby's development is at risk. It is amazing to realize that your loving care actually determines the very structure of your baby's brain!

Children also have "windows of opportunity" when it is particularly easy for them to learn certain skills. For example, the brain can most easily absorb and process new vocabulary words from birth to approximately three years of age. Therefore, this is an ideal time to speak to and read to your child to enhance his intellectual development.

By the second month of life, your baby will probably recognize some familiar faces and familiar voices. He may also recognize a favorite toy, and stare at people and objects he is drawn to. More than anything, your baby is delighted by your face. Lean over him and let him watch your lips move and your expressions change. He will especially like to see your smile!

\section{Parent Time}

Parenting an infant is very fulfilling, but it can be stressful at times. Research has found that babies as young as one month old can sense, and will be affected by, a parent who is depressed or angry. For your baby's well-being as well as your own, it is vital for

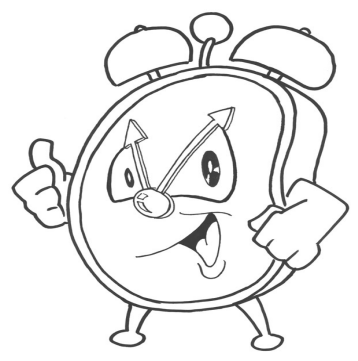
you to take care of yourself. Do not reject help from family and friends when you need it. Their support will keep you happy and healthy, which will greatly benefit your child. Letting family and friends help you creates ways for them to be involved with your baby, which builds a caring network for him, too.

Above all, find the delicate balance between meeting your needs and your baby's needs. 
Children grow best when parents maintain a positive outlook.

For couples who are first-time parents, the following recommendations can be of help during this new life phase:

* Share expectations. Talk with each other about what you see as the other's role and what you need from each other.

* Make time to talk to each other. Regularly check how your partner is doing.

* Keep a positive attitude; work on solutions to possible problems.

*Find support from family and friends.

\section{Reference List}

Allen, K. Eileen, and L. Marotz 1994. Developmental Profiles: Pre-birth Through Eight. New York: Delmar Publishers

Bales, D. 1998. Building Baby's Brain: The Basics. Retrieved March 23,2002, from the University of Georgia, College of Family and Consumer Sciences Wé 으 site: http://Www.fcs.uga.edu/pubs/PDF/FACS01 1.pdf

Berk, Laura, E. 2002. Infants and Children: Prenatal Through Middle Childhood $4^{\text {th }}$ Ed. Boston: Allyn \& Bacon.

Brooks, J.B. 1999. The Process of Parenting $5^{\text {th }} E d$. Mountain View, CA: Mayfield Publishing Co.

I Am Your Child Foundation. The First Years Last Forever: The New Brain Research and Your Child's Healthy Development. [Brochure].
Lamb, M.E., M.H. Bornstein, and D.M Teti. 2002. Development in Infancy $4^{\text {th }} E d$. Mahwah, NJ: Lawrence Erlbaum Associates.

Nelson, Patricia. 1995. Great Beginnings: A Series for Parents of Infants and Young Children. Retrieved March 26, 2002, from the University of Delaware, National Cooperative Extension Web site: http://ag.udel.edu/extension/fam/gb/gb-list.htm

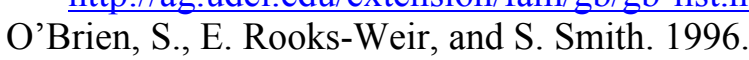
Your Baby's First Year: Development During Month One. Fact Sheet HE 2032.

O'Brien, S., E. Rooks-Weir, and S. Smith. 1996. Your Baby's First Year: Development During Month Two. Fact Sheet HE2033.

Santrock, John W. 1992. Life-Span Development. Dubuque, IA: Wm. C. Brown Publishers.

What Grown-ups Understand About Child Development. Retrieved June 18, 2002, from the Zero to Three Web_site: http://www.zerotothree.org/Archive/survey.htm White, Burton, L. 1995. The New First Three Years of Life. New York: Simon \& Schuster 